\title{
Recurrent Primary Mediastinal (Thymic) Large B-Cell Cell Lymphoma
}

National Cancer Institute

\section{Source}

National Cancer Institute. Recurrent Primary Mediastinal (Thymic) Large B-Cell Cell Lymphoma. NCl Thesaurus. Code C8874.

The reemergence of mediastinal (thymic) large B-cell lymphoma after a period of remission. 